\title{
43. THE MESSINIAN RECORD OF THE OUTCROPPING MARGINAL ALBORAN BASIN DEPOSITS: SIGNIFICANCE AND IMPLICATIONS ${ }^{1}$
}

\author{
José M. Martín, ${ }^{2}$ Juan C. Braga, ${ }^{2}$ and Isabel Sánchez-Almazo ${ }^{2}$
}

\begin{abstract}
The Messinian record of marginal Alboran basins, such as the Sorbas Basin in southern Spain, consists of a shallow-marine succession with intercalated evaporites. The pre-evaporite sequence comprises a bryozoan-bivalve, temperate-carbonate unit overlain by tropical carbonates. The latter, in turn, consists of two superimposed units: a bioherm unit with coral (Porites, Tarbellastraea, and Siderastraea) and algal (Halimeda) mounds, and a coral (Porites)-stromatolite fringing reef unit. Climatic fluctuations in the Alboran area, linked to the Neogene glacial-interglacial oscillations, are thought to be responsible for the change from temperate to tropical conditions.

Evaporites are mainly selenite gypsum deposits. The first post-evaporite unit is a mixed siliciclastic-carbonate marginal deposit, with small coral (Porites) patches and huge microbial (stromatolite and thrombolite) domes, changing basinward to silts and marls containing planktonic foraminifers.

An incised erosion surface was scoured on top of the pre-evaporitic fringing reef unit. This erosion surface formed during drawdown and desiccation of the Mediterranean Sea, when huge masses of salt were deposited in its center. Deposition of gypsum at the very margin of the Alboran Sea took place later in small, barred, satellite perched basins. In these silled basins marine incursions became more and more frequent until a full connection with the Mediterranean Sea was established by the end of the Messinian. Reflooding was completed during the Messinian, as demonstrated by the marine marls with planktonic foraminifers found on top of the evaporites. This situation is comparable to that of the western Mediterranean (DSDP Site 372; ODP Site 975), where the upper evaporites are directly overlain by Messinian marls with planktonic foraminifers. During the initial stages of marine recolonization, microbes coexisted with, but outcompeted, the normal marine biota. This resulted in the widespread proliferation of microbial carbonates (stromatolites and thrombolites).
\end{abstract}

\section{INTRODUCTION}

It is now widely accepted that during the Messinian (7.1-5.3 Ma; Berggren et al., 1995) the Mediterranean was cut off from the Atlantic and at least partially dried up. As a result of repeated desiccation, huge masses of evaporites were deposited in its most central, deepest parts (Hsü et al., 1973, 1977). The sequence of events connected to these processes of desiccation is known as the "Messinian Salinity Crisis" (see Hsü et al., 1973, 1977; Esteban, 1980; Rouchy, 1980, 1982; Benson et al., 1991; Cita, 1991; Riding et al., 1998; among others).

Although evaporite deposits are absent from the Alboran Basin in the westernmost Mediterranean (Comas et al., 1992), they do crop out extensively in the adjacent, deeper Balearic Basin (Hsü et al., 1978; Rouchy, 1986; Fig. 1). These evaporites are intercalated within a sequence of open-marine marls with sparse turbidites (Hsü et al., 1978), which in turn are well represented in the Alboran Basin (Comas et al., 1996).

Messinian coastal and shallow-marine deposits, laterally equivalent to the open-marine marls occurring in the Alboran Basin, crop out in some of the Neogene basins marginal to the western Mediterranean in southern Spain (Van de Poel, 1991, 1994; Michalzik et al., 1993; Martín and Braga, 1994; Esteban et al., 1996) and northern Morocco (Saint-Martin and Rouchy, 1986; Cunningham et al., 1994; Esteban et al., 1996, Cunningham et al., 1997). These basins, in fact, represent the uplifted margin of the former Neogene Alboran Basin. They also contain intercalated evaporites and have a marine record that allows reconstruction of the sequence of events leading to the major desiccation and the processes that followed immediately after-

IZahn, R., Comas, M.C., and Klaus, A. (Eds.), 1999. Proc. ODP Sci. Results, 161: College Station, TX (Ocean Drilling Program).

${ }^{2}$ Departamento de Estratigrafía y Paleontología, Universidad de Granada, Campus de Fuentenueva, s.n. 18002 Granada, Spain. Martín: jmmartin@goliat.ugr.es ward. Some of the better preserved and studied marine Messinian, marginal Alboran Basin outcrops are to be found in southern Spain, specifically in the Sorbas Basin (Martín and Braga, 1994; Riding et al., 1998), used here as the type example.

\section{THE MARGINAL-ALBORAN MESSINIAN STRATIGRAPHIC RECORD}

In southern Spain, only those basins close to the present-day Mediterranean, such as the Sorbas Basin (Fig. 1), were marine during the Messinian, with the exception of an interval corresponding to evaporative drawdown and evaporite deposition (Martín and Braga, 1994; Riding et al., 1998). Basins located further inland, such as the Granada and Guadix basins (Fig. 1), were disconnected from the main Mediterranean, a result of tectonic uplift, just before or during the early Messinian and have a mainly continental Messinian record (Dabrio et al., 1982; Martín et al., 1984; Braga et al., 1990; Fernández et al., 1996; Riding et al., 1998).

In the Sorbas and nearby Almería basins in southern Spain, the Messinian sequence is up to $320 \mathrm{~m}$ thick, and consists of five units (Martín and Braga, 1994; Fig. 2). First is a temperate-carbonate unit, consisting of bioclastic calcarenites, changing basinward into marls, with abundant remains of bryozoans, bivalves, corallines, and benthic foraminifers and minor brachiopods, solitary corals, barnacles, and gastropods (Martín et al., 1996). This biota association is a "foramol-type association" in the sense of Lees and Buller, 1972 (also called "rhodalgal association," Carannante et al., 1988; or "bryomol association," Nelson et al., 1988) and is typical of temperate, shelf carbonates. The Tortonian/Messinian boundary (7.1 Ma; Berggren et al., 1995) is found within the basinal marls laterally equivalent to the temperate carbonates (Sierro et al., 1993; Gautier et al., 1994), which are at least partly upper Tortonian. Oxygen-isotope studies made on planktonic foraminifer tests from these marls yield an average sea-surface paleotemperature of $16^{\circ}$ (Sánchez-Almazo et al., 1997) (Table 1). 


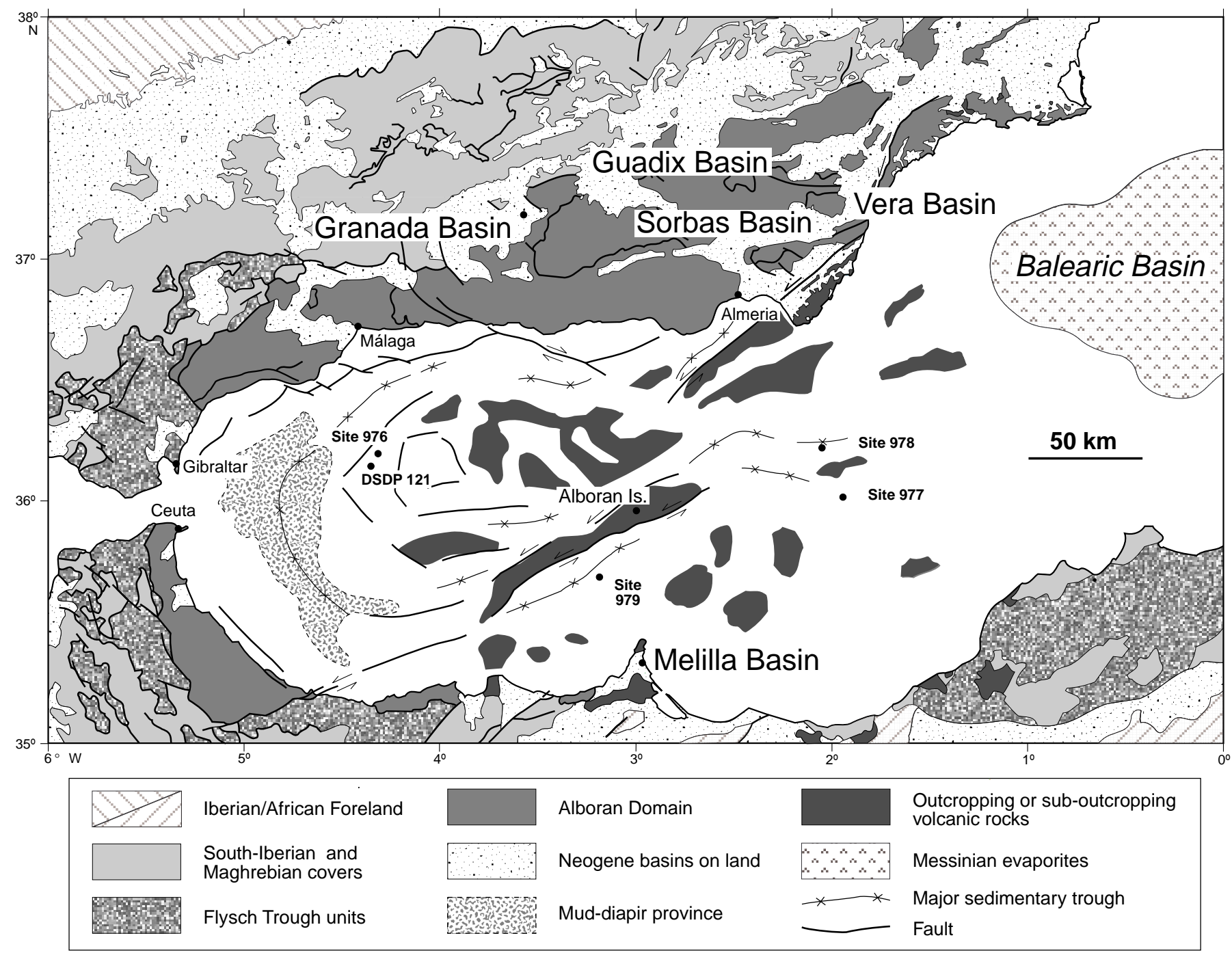

Figure 1. Simplified geological sketch of the marginal Alboran area (modified from Comas et al., 1996) showing major Neogene basins in southern Spain and northern Morocco and the location of sites referred to in the text.

The second unit is a bioherm unit consisting of tropical platform carbonates with intercalated lensoid, coral patch reefs, and Halimeda mounds (Braga et al., 1996a). The Halimeda mounds developed in a distal position, on the marly, frontal slopes of the platforms (Martín et al., 1997). The coiling change in Neogloboquadrina acostaensis yields an absolute age of 6.2 Ma (using Berggren et al.'s 1995 time scale) for the marls laterally equivalent to the bioherm unit (Braga and Martín, 1996). These marls intercalate with diatomites and contain abundant planktonic foraminifers. Average sea-surface paleotemperatures, estimated from oxygen isotopes from planktonic foraminifer tests, rose to $24^{\circ}$ at the time when bioherms developed (Sánchez-Almazo et al., 1997; Table 1).

Third is a unit consisting of Porites coral-stromatolite, prograding fringing reefs (Dabrio et al., 1981; Riding et al., 1991b; Braga and Martín, 1996). This reef unit passes laterally, basinward, into marls, with intercalated diatomites, containing abundant calcareous nannoplankton (Martín-Pérez, 1989) and planktonic foraminifers (e.g., Globorotalia mediterranea) of Messinian age (Iaccarino et al., 1975; Serrano, 1979; Toelstra et al., 1980; Sierro et al., 1993; Gautier et al., 1994). Magnetostratigraphy (Gautier et al., 1994) indicates the start of Chron 3R (5.9 Ma [Berggren et al., 1995]; 5.7 Ma [Baksi, 1993]) at the top of the marls. Average sea-surface paleotemperatures, esti- mated again from oxygen isotopes from planktonic foraminifer tests slightly decreased to $21^{\circ}$ while Porites fringing reefs developed (Sánchez-Almazo et al., 1997; Table 1).

Selenite gypsum deposits (evaporite unit) represent the fourth unit, with a maximum thickness of $130 \mathrm{~m}$ (Dronkert, 1977). These overlie a basin-scale, major unconformity on top of the fringing-reef unit (Riding et al., 1991b; Martín and Braga, 1994; Riding et al., 1998). They onlap the eroded reef slopes (Braga and Martín, 1992), occurring as thick banks (up to $20 \mathrm{~m}$ thick) of vertically arranged, twinned, selenite gypsum crystals, separated by silt-marl interbeds (up to $3 \mathrm{~m}$ thick; Dronkert, 1977). Cauliflower-like structures ("supercones"), formed depositionally during gypsum growth, are characteristic features in the upper part of the gypsum sequence (Dronkert, 1977). In the uppermost part (20-30 top m of the gypsum sequence) the gypsum intercalates with beds (up to 5-6 m thick) of marine silts and marls containing unreworked foraminifers. Four genera of benthic and 14 species of planktonic foraminifers have been identified, the latter including Globorotalia gr. miotumida sensu Sierro et al. (1993), Neogloboquadrina acostaensis, and Globigerina multiloba that yield a Messinian age (Riding et al., 1998). The recorded planktonic foraminifers are dwarfed, adult forms with well-preserved tests. Neither juvenile forms nor broken tests of normal-sized, 


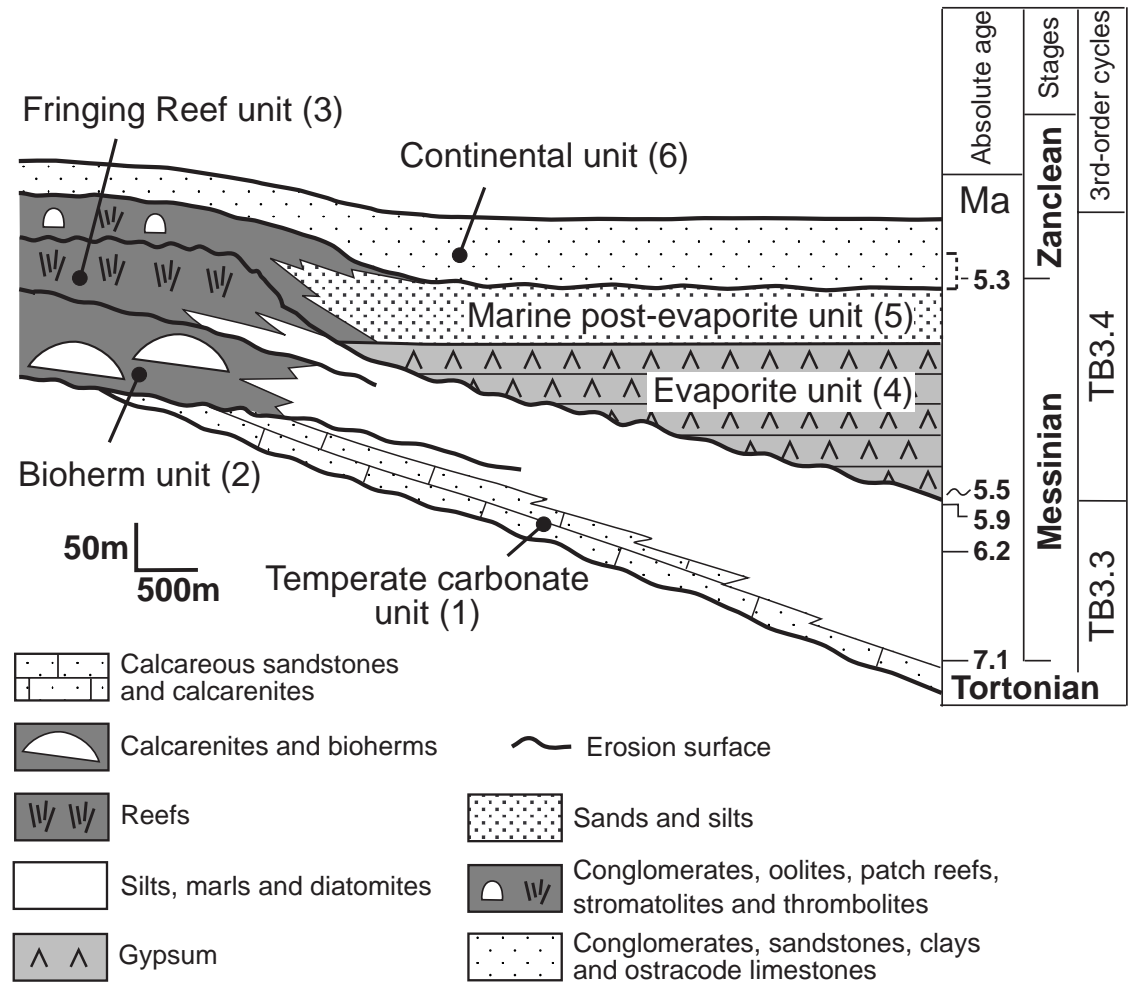

Figure 2. Latest Tortonian to early Pliocene stratigraphy of Neogene basins in southern Spain placed at the very margin of the Alboran Sea (modified from Martín and Braga, 1994). Absolute age values after Berggren et al. (1995). Note how the unconformity on top of the fringing reef extends also below the gypsum in the center of the Sorbas Basin. The relief related to this unconformity has been calculated simply by measuring the vertical distance between the base of the lowermost gypsum layer and the top of the fringing reef.

Table 1. Estimated sea-surface paleotemperatures calculated from $\delta^{18} \mathrm{O}$ values from planktonic foraminifer tests of selected samples from the basinal marls of the different Messinian units.

\begin{tabular}{|c|c|c|c|c|c|c|c|}
\hline Units & Samples & Species & $\begin{array}{l}\delta^{18} \mathrm{O} \\
(\% o)\end{array}$ & $\begin{array}{l}\delta^{13} \mathrm{C} \\
(\% o)\end{array}$ & $\begin{array}{c}\mathrm{T} \\
\left({ }^{\circ} \mathrm{C}\right)\end{array}$ & $\begin{array}{c}\mathrm{T} \\
\text { (mean) }\end{array}$ & $\begin{array}{r}\delta^{18} \mathrm{O} \\
(\text { mean })\end{array}$ \\
\hline $\begin{array}{l}\text { Post-evaporite } \\
\text { marine unit }\end{array}$ & $\begin{array}{l}\text { NCS-11 } \\
\text { NCS-10 } \\
\text { NCS-9 } \\
\text { NCS-9 }\end{array}$ & $\begin{array}{l}\text { G. trilobus } \\
\text { G. trilobus } \\
\text { G. trilobus } \\
\text { G. trilobus }\end{array}$ & $\begin{array}{l}-0.91 \\
-0.88 \\
-0.49 \\
-0.2\end{array}$ & $\begin{array}{r}-0.24 \\
-0.79 \\
0.63 \\
-0.36\end{array}$ & $\begin{array}{l}22 \\
22 \\
20 \\
19\end{array}$ & 21 & -0.62 \\
\hline Evaporite unit & LRA-8 & G. trilobus & -0.44 & 0.51 & 20 & 20 & -0.44 \\
\hline $\begin{array}{l}\text { Fringing reef } \\
\text { unit }\end{array}$ & $\begin{array}{l}\text { CA-5 } \\
\text { CA-4 } \\
\text { CAF-6 } \\
\text { CA-3 } \\
\text { CAF-4 } \\
\text { CA-2 } \\
\text { CAF-3 }\end{array}$ & $\begin{array}{l}\text { O. universa } \\
\text { O. universa } \\
\text { O. universa } \\
\text { O. universa } \\
\text { O. universa } \\
\text { O. universa } \\
\text { O. universa }\end{array}$ & $\begin{array}{r}-1.00 \\
-1.32 \\
0.56 \\
-1.35 \\
-0.03 \\
-1.42 \\
-0.05\end{array}$ & $\begin{array}{l}0.63 \\
1.03 \\
0.95 \\
1.05 \\
2.06 \\
1.61 \\
1.19\end{array}$ & $\begin{array}{l}23 \\
24 \\
16 \\
24 \\
16 \\
24 \\
18\end{array}$ & 21 & -0.66 \\
\hline Bioherm unit & $\begin{array}{l}\text { LT-1 } \\
\text { LT-2 }\end{array}$ & $\begin{array}{l}\text { O. universa } \\
\text { O. universa }\end{array}$ & $\begin{array}{l}-1.68 \\
-0.86\end{array}$ & $\begin{array}{r}-0.70 \\
0.13\end{array}$ & $\begin{array}{l}26 \\
22\end{array}$ & 24 & -1.27 \\
\hline $\begin{array}{l}\text { Temperate-carbonate } \\
\text { unit }\end{array}$ & $\begin{array}{l}\text { LT-4 } \\
\text { LT-6 } \\
\text { LT-7 } \\
\text { LT-8 } \\
\text { LT-9 } \\
\text { LT-10 } \\
\text { LT-3 } \\
\text { LT-11 } \\
\text { LT-12 } \\
\text { LT-0 }\end{array}$ & $\begin{array}{l}\text { O. universa } \\
\text { O. universa } \\
\text { O. universa } \\
\text { O. universa } \\
\text { O. universa } \\
\text { O. universa } \\
\text { O. universa } \\
\text { O. universa } \\
\text { O. universa } \\
\text { O. universa }\end{array}$ & $\begin{array}{r}0.73 \\
1.04 \\
0.98 \\
0.69 \\
0.66 \\
1.05 \\
0.84 \\
0.14 \\
-0.11 \\
-1.00\end{array}$ & $\begin{array}{l}1.10 \\
1.045 \\
1.29 \\
1.12 \\
0.495 \\
1.30 \\
1.495 \\
0.51 \\
0.93 \\
-0.48\end{array}$ & $\begin{array}{l}15 \\
14 \\
14 \\
15 \\
15 \\
14 \\
15 \\
18 \\
18 \\
22\end{array}$ & 16 & 0.50 \\
\hline
\end{tabular}

Notes: Samples are from bottom to top and were taken at regular intervals of different magnitude for each unit. Only in the upper half of the fringing reef unit were samples taken. The sample of the evaporite unit is from the silt-marl interbeds of the topmost part of the unit. Average sea-surface paleotemperatures agree well with the climatic attribution (temperature or tropical) for the carbonate units. Departures from tropical values (less than $20^{\circ}$ ) in the fringing reef unit are related to the low-stand deposits (low-stand wedges of Braga and Martín, 1996) of the high-frequency (precesion) cycles, which have a temperature character.

adult foraminifers of Messinian or older ages have been found. Average sea-surface paleotemperatures of $20^{\circ}$ have been estimated from the isotopic analysis of the tests of some of these planktonic foraminifers (Sánchez-Almazo et al., 1997; Table 1).

The last (fifth) Messinian unit corresponds to siliciclastic sands and conglomerates, with local oolitic carbonates and coral (Porites) patch reefs, changing laterally to silts and marls and intercalating gi- ant (up to $15 \mathrm{~m}$ in diameter) microbial (stromatolite-thrombolite) domes (Roep et al., 1979; Riding et al., 1991a; Martín et al., 1993; Braga et al., 1995). The marls in this unit contain 13 benthic genera and 15 planktonic species, including again Globorotalia gr. miotumida sensu Sierro et al. (1993), Neogloboquadrina acostaensis, and Globigerina multiloba (Riding et al., 1998), and is also Messinian. Average sea-surface paleotemperatures of $21^{\circ}$ have been estimated 
from planktonic foraminifers from these marls (Sánchez-Almazo et al., 1997; Table 1).

A higher unit (number 6 in Fig. 2), consisting of alluvial and fluviatile conglomerates and sands passing laterally to lacustrine and estuarine silts and ostracode limestones, is found on top of the sequence and is considered to be Pliocene (Martín and Braga, 1994), although a Messinian age, at least for its lower part, cannot be discounted (Roep et al., 1979; Ott d'Estevou, 1980).

Stratigraphic complexities found in the Messinian record of the Sorbas Basin are believed to be the result of eustatic sea-level changes combined with local tectonic activity (Martín and Braga, 1996). The Messinian stratigraphic record can be divided into two depositional sequences (Braga and Martín, 1992; Martín and Braga, 1994; Fig. 2). The lower one comprises temperate carbonates and bioherm and fringing reef units. They represent, respectively, the lowstand, transgressive, and highstand of a third-order cycle, which can be correlated with the TB 3.3 cycle of Haq et al. (1987). The upper sequence comprises gypsum deposits, an overlying siliciclasticstromatolitic unit, and alluvial-lacustrine siliciclastic deposits on top. The gypsum deposits (unit 4) and the two overlying units (5 and 6) represent once again the lowstand, transgressive, and highstand system tracts of a third-order cycle, and as such could be correlated with the TB 3.4 cycle of Haq et al. (1987). The evaporites are thus most likely related to the cold span of the upper Messinian third-order cycle.

\section{SEDIMENTARY INTERPRETATION AND SEQUENCE OF EVENTS}

The sequence of events that can be deduced from the stratigraphic record is as follows: (1) deposition of the temperate carbonates and formation of the reef units; (2) drawdown and basin-scale erosion; (3) deposition of the evaporites; and (4) deposition of the last Messinian marine unit that includes the stromatolites.

\section{Pre-Evaporite Events}

As mentioned above, the uppermost Tortonian/lower Messinian temperate carbonates formed during the lowstand of a third-order cycle (Martín and Braga, 1994). They were deposited during the cold phase of the lower (pre-evaporitic) Messinian cycle. Tropical carbonates with coral reefs formed as sea level rose and seawater temperature went up, as demonstrated by the stratigraphic and geometrical field-relationships (Brachert et al., 1996; Braga and Martín, 1996) and the paleotemperature estimations (Sánchez-Almazo et al., 1997) (Table 1). A temperate record based on foraminiferal assemblages within basal Messinian marls has also been reported in northern Morocco (Benson et al., 1991).

Climatic conditions swung between temperate and tropical several times during the late Neogene in the study area, and not only in the Messinian (Martín and Braga, 1994; Brachert et al., 1996; Esteban et al., 1996) (Fig. 3). Starting in the late Miocene, the first temperate episode corresponds to the early Tortonian. It is succeeded by a tropical phase in the late Tortonian. The next temperate span is late Tortonian/early Messinian. Tropical conditions prevailed again for most of the Messinian, except for a short intra-Messinian interval. Temperate conditions were established afterward in the Pliocene, extending up to the present.

The Mediterranean area has been specially sensitive to climatic oscillations. The present-day limit between the temperate and tropical climatic zones is just south of, and close to, the Mediterranean Sea. The climatic variations induced by the Neogene third-order cycles (probably connected to major glaciations: Shackleton, 1984; Kendall and Lerche, 1988; Williams, 1988; Müller et al., 1991) implied significant changes in the latitudinal position and amplitude of

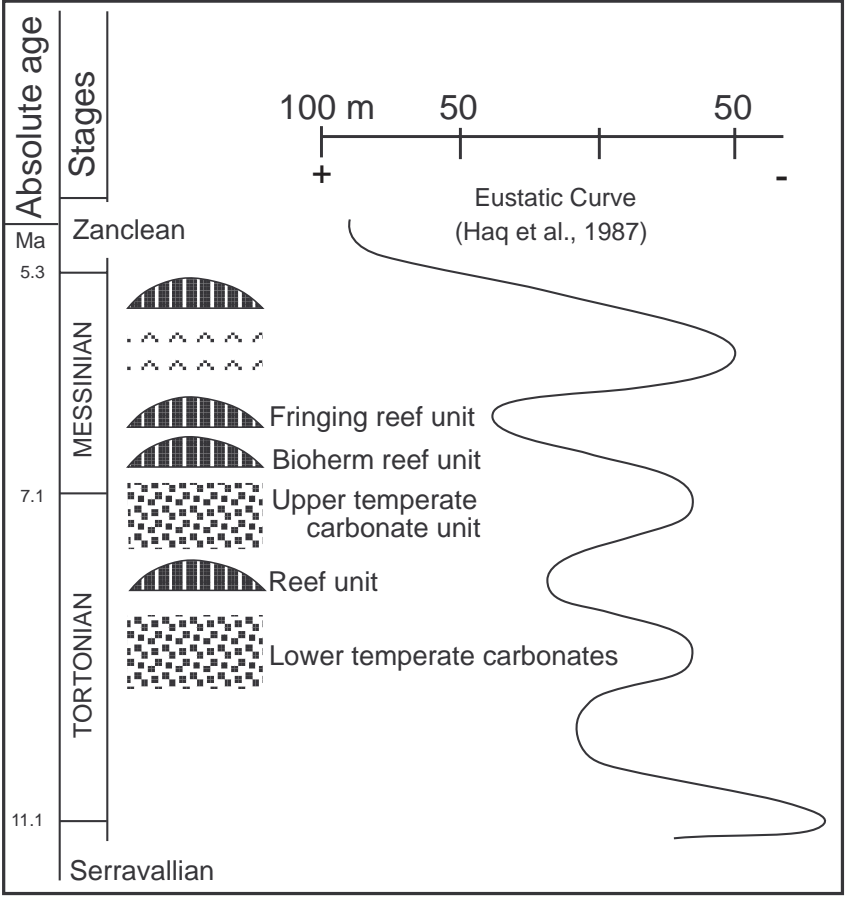

Figure 3. Temporal distribution of temperate and tropical (reef) carbonates in southern Spain during the Neogene (modified from Brachert et al., 1996 and Braga et al., 1996b) and their correlation to the eustatic curve of Haq et al. (1987). Temperate carbonates were deposited during low sea levels of thirdorder cycles while coral reefs grew during high sea levels. Note that Messinian evaporites formed during the cold phase (low sea-level stand) of a thirdorder cycle.

the temperate and tropical climatic belts, as well as the displacement of the temperate/tropical boundary to the south during the cold stages and to the north during the warm ones. In cold periods the Mediterranean Sea was temperate, becoming tropical during the warm episodes (Martín and Braga, 1994). These fluctuations between temperate and tropical climates were probably accompanied by significant changes in water-current patterns within the western Mediterranean (Martín and Braga, 1994; Fig. 4). During temperate periods, as happens today, cold Atlantic surface water entered the Mediterranean and temperate shelf facies developed in the Alboran area. Mediterranean waters flowed outward in deeper layers and storm-induced mixing of water within the Mediterranean precluded stratification (Martín and Braga, 1994). During tropical periods, warmer surface water spread into the western Mediterranean from the east across cold, bottomrelated Atlantic waters, resulting in thermal stratification and promoting the development of coral reefs along the Alboran margins. In contrast, on the Atlantic side of Iberia and Morocco surface waters were too cold to allow reef growth. Deposition of basinal euxinic facies and diatomites lateral to the reefs reflects bottom restriction, together with local upwelling (Martín and Braga, 1994; Martín et al., 1997). $\Delta \delta^{13} \mathrm{C}$ values from benthic and planktonic foraminifers also point to water stratification during the reef-growth phases (Sánchez-Almazo et al., 1997).

This climatic swings recorded in the Messinian carbonates are part of a larger-scale process, related to the global climatic evolution during the Neogene, and not specifically to the Messinian Salinity Crisis. Paleotemperature estimates (Table 1) confirm this climatic control on the biogenic associations of the Neogene carbonates from southern Spain (Sánchez-Almazo et al., 1997).

Messinian coral reefs from the Alboran Margin show a progressive decrease in diversity that initiated in the Tortonian. Porites, Tar- 


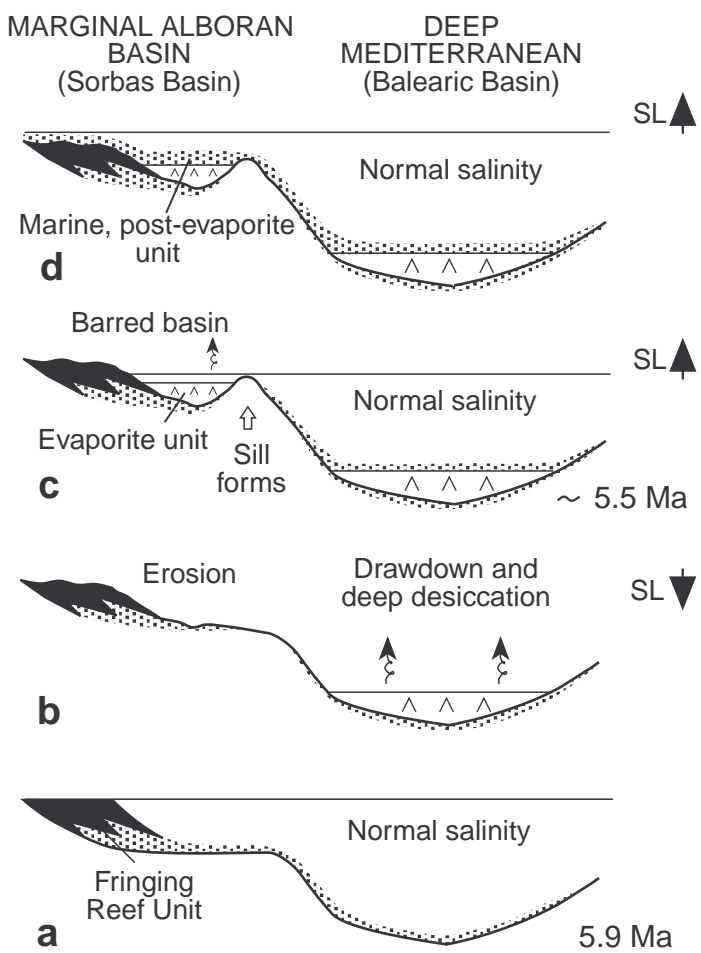

Figure 4. Messinian evolution of marginal basins, such as the Sorbas Basin in southern Spain, with respect to the deep Mediterranean (A-D). Note that in this model, evaporite deposition in the marginal Alboran areas (C) took place after drawdown and main desiccation (B) as the basins became silled and barred as a result of uplifting. Marine reflooding (D) is believed to have been completed before the end of the Messinian (modified from Riding et al., 1998).

bellastraea, and Siderastraea are the only corals in the bioherm unit (Martín and Braga, 1991). The Messinian fringing reefs are built by Porites and very minor Siderastraea, with the Porites heavily encrusted by stromatolites (Riding et al., 1991b). Long (up to 3-4 m), thin (up to a few centimeters), stick-like forms are the predominant growth morphologies of Porites in these reefs (Esteban et al., 1978; Esteban, 1980), except for the reef crest, where thin (millimeter to centimeter scale), contorted, laminar growths occur (Riding et al., 1991b). Although these peculiar growth forms and composition were originally considered a consequence of slightly abnormal salinities (Esteban et al., 1978), they more probably relate to the growth of these reefs in a very marginal position, close to the limits of the tropical reef belt (Chevalier, 1961; Martín and Braga, 1994). Bivalve associations within the reefs suggest similar conclusions (Jimenez and Braga, 1993).

\section{Drawdown and Basin-Scale Erosion}

Mediterranean Sea deep desiccation resulted in the deposition of more than a thousand meters of salt on its floor (Hsü et al., 1973, 1978; Rouchy and Saint-Martin, 1992). At the time that these basincenter evaporites formed, the marginal Alboran Basin area was emerged and subject to erosion. This resulted in a major unconformity affecting the top of the fringing reef unit (Dabrio et al., 1981; Riding et al., 1991b; Martín and Braga, 1994; Riding et al., 1998). The relief related to this unconformity is, in the case of the Sorbas Basin, at least $240 \mathrm{~m}$ (Riding et al., 1998).

Biostratigraphic and magnetostratigraphic data indicate that the fringing reef unit developed in no more than a few hundred thousand years (Braga and Martín, 1996). Reef-facies distribution and geometries reveal cyclic sea-level changes during reef development. Two orders of cyclicity can be recognized: the long-term cycles have an estimated relative sea-level change of about $100 \mathrm{~m}$, while the shortterm cycles have an amplitude of several tens of meters. A detailed analysis of the internal geometry of these reefs shows how reef growth was suddenly interrupted during the ascending phase of one of the long-term (short-eccentricity) cycles (Braga and Martín, 1996). This latter situation can only be explained by a tectonic pulse (Martín and Braga, 1996), which could also have been responsible for the uplifting and closure of the straits connecting the Atlantic and the Mediterranean, located at that time in the Rif area, on the southern Alboran Margin in northern Morocco (Esteban et al., 1996). This supports Weijermars' (1988) ideas suggesting tectonic control for the closing of the Mediterranean, and, consequently, a tectonic origin for the Salinity Crisis.

Age calibrations of the different Messinian units represented at the margin of the Alboran Basin, together with some theoretical calculations, suggest a relatively short duration for the Salinity Crisis, lasting no longer than 400,000 years (using Berggren et al.'s scale $=$ 200,000 years on Baksi's 1993 time scale; Riding et al., 1998). The age of the uppermost marls laterally equivalent to the fringing reef is, as mentioned above, 5.9 Ma (5.7 Ma on Baksi's scale). The Messinian/Pliocene boundary is placed at 5.3 Ma on both scales. The marginal evaporites and the overlying siliciclastic-stromatolite unit are each considered to have been deposited in a 100,000-year interval (Riding et al., 1998). This leaves a 400,000-year interval for the deposition of the evaporites in the center of the Mediterranean. This period would seem to be even shorter $(120,000-130,000 \mathrm{yr}$ or less), according to the radiometric dating presented by Cunningham et al. (1994) and Cunningham et al. (1997), for the fringing reef and the uppermost marine Messinian units cropping out near Melilla in northern Morocco.

\section{Evaporite Deposition}

Evaporites (gypsum deposits) from the marginal Alboran basins closer to the present-day Mediterranean, such as the Sorbas Basin, are thought to have been deposited later during reflooding of the Mediterranean, after drawdown (Riding et al., 1998) (Fig. 4). Sulfur $\left(\delta^{34} \mathrm{~S}\right.$ values ranging between $+23.5 \%$ and $22.0 \%$ ) and strontium $\left({ }^{87} \mathrm{Sr} /\right.$ ${ }^{86} \mathrm{Sr}$ values ranging between 0.70893 and $0.70895 \pm 10^{-5}$ ) isotope data are both clearly within the range for Messinian marine waters (Claypool et al., 1980; Hodell et al., 1989; Müller and Mueller, 1991) and indicate a marine origin for the gypsum (Playà et al., 1997). Most of this gypsum formed subaqueously, crystallizing directly on the bottom of the brine.

The Sorbas Basin shows a complex paleogeographical evolution from the upper Tortonian onward, reflecting its progressive restriction and isolation (Fig. 5). Sierra Alhamilla, the present-day southern margin relief, first emerged during the latest Tortonian. Temperate shelf carbonates were deposited at that time, and, during the early Messinian, around the emerging Sierra Alhamilla and on the northern margin of the basin. Messinian reefs formed afterward and can be traced for kilometers along both margins of the basin. The Sorbas Basin was then a very narrow, east-west-trending corridor almost closed to the west, becoming completely cut off at that point before the deposition of the next Messinian unit (gypsum unit). When the gypsum formed, the basin was only open to the east (Braga and Martín, 1997), although a sill, placed just at the eastern entrance of the basin, limited the connection with the open Mediterranean Sea up to a certain extent. This sill was located in the area of "Los Castaños," just $10 \mathrm{~km}$ east of Sorbas. Basement outcrops of the Sierra de Filabres to the north and Sierra Cabrera (the eastern continuation of Sierra Alhamilla) to the south are only $4 \mathrm{~km}$ apart at this point, with another outcrop of the same basement occurring just in the middle of the other 
Figure 5. Late Miocene paleogeographical evolution of the Sorbas Basin (modified from Braga and Martín, 1997). A. During the late Tortonian, the basin was completely open to the south (Braga and Martín, 1992; Martín and Braga, 1996). Small carbonate platforms with local coral reefs developed at its northern margin (southern flank of Sierra de los Filábres). A huge submarine fan with thick turbidite deposits formed in the northwestern part of the basin (Tabernas area; Kleverlaan, 1989). A smaller fan was located to the east, in the middle of the basin (Haughton, 1994). The present-day southern relief (Sierra Alhamilla) was, at that time, a pelagic swell several hundred meters deep. B. Sierra Alhamilla started to emerge during the latest Tortonian. Temperate shelf carbonates were deposited at that time, and during the earliest Messinian, at both margins of the basin. C. When the Messinian reefs formed, the Sorbas Basin was a narrow, east-west-trending corridor. D. During deposition of the gypsum unit, the basin was only open to the east, with a sill (between "Sierra de Filabres" and "Sierra Cabrera") restricting its connection to the open sea. E. During deposition of the last Messinian unit, the basin was open to the east and presumably to the south as well.

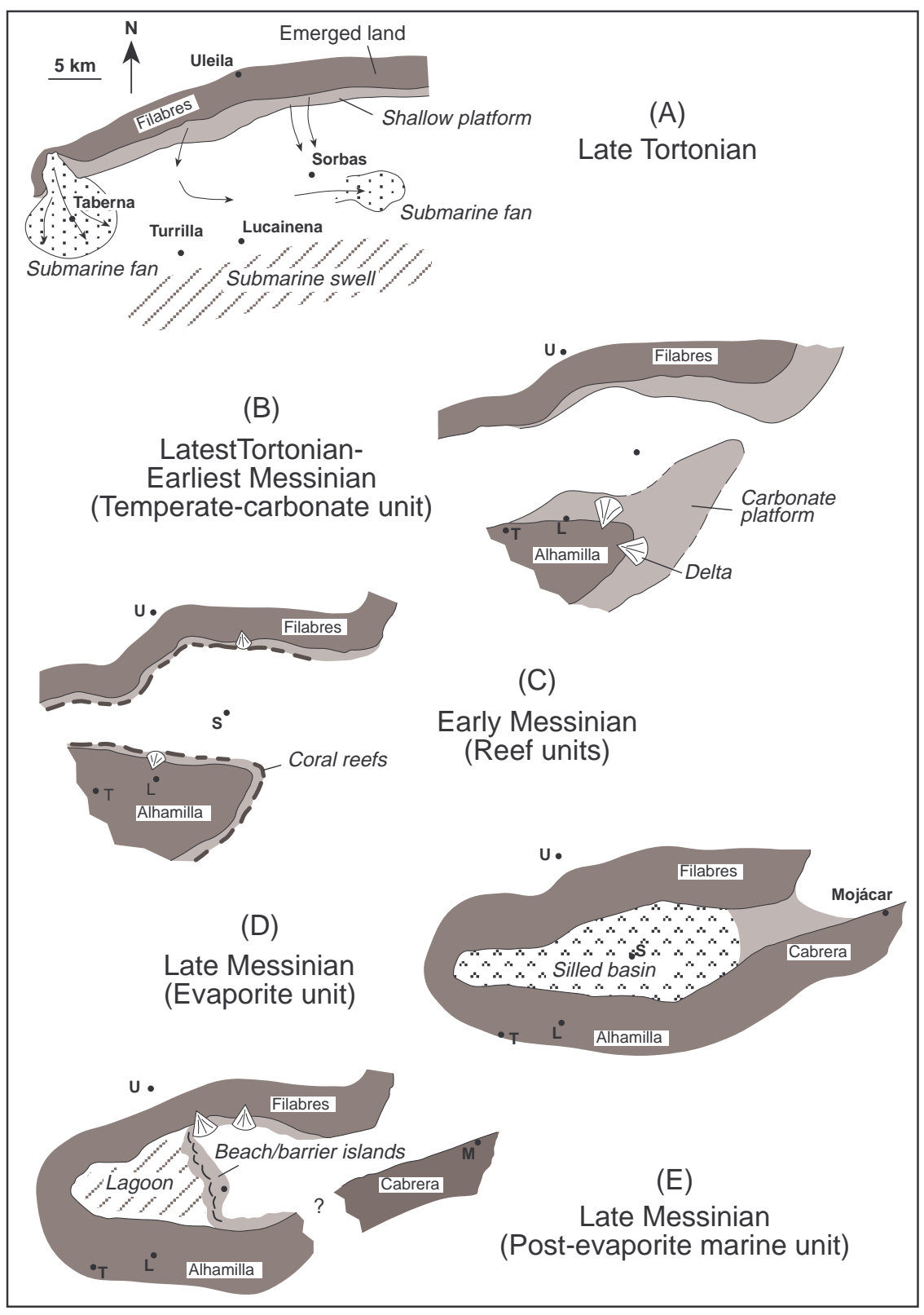

two (see 1:100,000 geological map of Montenat [1990]). During deposition of the last Messinian unit, the basin was open to the east and, presumably, to the south as well (Braga and Martín, 1997). The basin was completely uplifted during the late Pliocene (Mather, 1993).

This complex history reflects a considerable synsedimentary tectonic activity and very clearly indicates that the deposition of the gypsum took place in a small, satellite perched basin, temporarily isolated with respect to the main Mediterranean as a result of local uplifting (Riding et al., 1998).

The classic, barred basin model (Sonnenfeld, 1985) could be applied to explain the formation of evaporites in these basins from normal seawater flooding across the sills. In these marginal Alboran silled basins, marine incursions became more and more frequent until a full connection was established by the end of the Messinian. Siltmarl interbeds reflect normal marine incursions at the time of gypsum deposition. There exists a gradual transition from the evaporites to the silts and marls of the uppermost marine Messinian unit, as shown by the silt-marl interbeds in the uppermost gypsum sequence contain- ing a planktonic foraminifer assemblage similar to that of the overlying unit (Riding et al., 1998).

\section{Post-Evaporite Events}

Large microbial carbonate domes (stromatolites and thrombolites) developed extensively at the margins of the Alboran Basin during the uppermost Messinian. They occur in the unit overlying the evaporites in a variety of environments, including fan deltas (Martín et al., 1993; Braga et al., 1995), beaches, and oolitic shoals (Riding et al., 1991a). Their abundance is comparable in many respects to their presence in the Precambrian (Martín and Braga, 1994), when stromatolite-forming microbes proliferated widely in the absence of other organisms that could compete with them (Garrett, 1970). There is, however, an important difference: in the Messinian examples an impoverished, normal-marine biota of corals (Porites), coralline algae, serpulids, bivalves, and encrusting foraminifers coexisted with the microbes (Martín et al., 1993; Braga et al., 1995), which rules out the 
possibility of abnormal salinities, suggested by several authors (Esteban, 1980; Rouchy and Saint-Martin, 1992), to account for the occurrence and proliferation of these structures. The most plausible explanation is that microbes acted as opportunistic biota and, for a time, outcompeted other organisms, settling and growing successfully in most of the available environments (Martín and Braga, 1994). This happened during the initial stages of marine recolonization of the Mediterranean Sea, after drawdown and deposition of the evaporites. The development of microbial structures during the uppermost Messinian thus seems to be related, although indirectly, to the Salinity Crisis.

Comparable situations are found in the Silurian of Michigan (Sears and Lucia, 1979) and the Permian of the Zechstein Basin (Paul, 1980), where significant stromatolite deposits lie directly on top of evaporites. The abundance of stromatolites in normal marine environments in the aftermath of mass extinctions of the pre-existing benthic biota has been explained in the same way (Schubert and Bottjer, 1992).

It should be noted that the last Messinian reefs survived the Salinity Crisis. They occur in this same Messinian uppermost unit (fifth unit above), together with the giant microbial domes. This latter unit clearly overlies the evaporites.

The basin silts and marls laterally equivalent to the coastal and shallow-marine facies with microbial carbonates have unreworked, small, planktonic foraminifers (see above), together with marine ostracodes (Nachite, 1993) and calcareous nannoplankton. This unit, placed immediately on top of the evaporites, represents the final stages and the completion of the marine reflooding, which is undoubtedly Messinian in age (Riding et al., 1998). A comparable situation is found in the western Mediterranean, where the upper evaporites are directly overlain by Messinian marls with small, planktonic foraminifers (DSDP Site 372 [Hsü et al., 1977; Hsü et al., 1978, p. 78; Cita et al., 1978, p. 1013]; ODP Site 975 [Comas et al., 1996, p. 133]). This latter unit can thus be correlated with that occurring immediately on top of the gypsum in the Balearic Basin (DSDP Site 372 [Hsü et al., 1978]; ODP Site 975 [Comas et al., 1996]) and with the topmost Messinian marls drilled in the Alboran Sea (Comas et al., 1996). The existence of this Messinian normal marine unit on top of the evaporites argues against the long-held view of early Pliocene (Zanclean) reflooding (Hsü et al., 1977; Müller and Hsü, 1987; Benson et al., 1991; Cita, 1991).

Some authors support the existence, for a time, of brackish (Lago Mare) conditions in the western Mediterranean, before the marine Pliocene inundation and immediately after the deposition of the evaporites (Ruggieri, 1967; Hsü et al., 1977; Cita, 1991; Comas et al., 1996). In fact, the presence of Ammonia tepida, in the uppermost Messinian marls lying immediately on top of the upper evaporites and drilled at Site 975 (Sample 161-975B-33X-CC [302.7 mbsf; Comas et al., 1996, p. 137]), is considered to be demonstrative of the existence of Lago Mare conditions in the western Mediterranean during the uppermost Miocene. It must be stated, however, that Ammonia tepida (a benthic foraminifer that may live in brackish, normal marine, or hypersaline waters [Murray, 1991]) appears in the same sample associated with planktonic foraminifers, such as G. conomiozea, G. mediteranea, G. miotumida, G. merotumida, and Neogloboquadrina acostaensis (sinistral coiling; Comas et al., 1996, p. 133), which are exclusively normal marine. This assemblage characterizes the Globorotalia conomiozea Zone and is the same one found in the Sorbas Basin in the silt-marl interbeds within the upper part of the gypsum unit, and in the marine Messinian marls lying on top of the evaporites.

Lago Mare facies are also thought to have formed in some of the marginal Alboran basins in southern Spain, specifically in the Vera Basin (Fig. 1), just to the east of, and very close to, the Sorbas Basin, and connected directly to the Mediterranean (Cita et al., 1980; Geerlings et al., 1980; Fortuin et al., 1995). This assumption is based on the existence of a silt sequence, underlying marine Pliocene marls and containing abundant brackish-water ostracodes and characeans, that the above-mentioned authors considered to be a typical Lago Mare facies. Dating of the sequence has proved to be complicated and is made more so by the existence of a critical unexposed 7-m interval just below the silt sequence (Fortuin et al., 1995; Fig. 4). In our view, and following Benson and Rakic-El Bied (1991), this silt sequence was deposited in an estuary, as can be inferred from the ostracode association. This sequence is also laterally equivalent to the uppermost Messinian(?)-Pliocene fluviatile and ostracode-characean lacustrine deposits (unit 6 in Fig. 2) cropping out in the Sorbas Basin (Riding et al., 1998). These latter deposits directly overlie the marine Messinian marls with planktonic foraminifers (unit 5 in Fig. 2) that postdate the evaporites. It is, therefore, difficult to attribute the silt sequence of the Vera Basin to a Lago Mare situation, in the sense of Hsü et al. (1977), because it seems to be a coastal, brackish deposit laterally equivalent to sediments post-dating the marine Messinian marls deposited directly over the evaporites.

\section{CONCLUSIONS}

The temperate carbonates at the base of the Messinian sequence were deposited during the cold phase of a third-order cycle. They were succeeded by tropical carbonates with coral reefs. Fluctuations of the climatic belts during the Neogene glacial-interglacial episodes induced the alternations between temperate and tropical conditions in the Alboran area.

Messinian coral reefs from the Alboran Margin show a progressive decrease in diversity that began in the Tortonian. The Messinian fringing reefs are almost exclusively constructed by Porites, heavily encrusted by stromatolites. They grew in a very marginal position, close to the limits of the tropical reef belt. The decrease in coral diversity during the Miocene is interpreted in terms of progressive cooling.

The Salinity Crisis happened very suddenly as a consequence of the tectonic closing of the Atlantic-Mediterranean connections and subsequent Mediterranean isolation. None of the features present in the pre-evaporitic units (such as the temperate-tropical oscillation, or the reef characteristics: coral growth-forms, coral diversity, composition, and stromatolite crusts) point to, or have any relation with, salinity variations induced by progressive isolation. Thermal stratification caused bottom restriction and favored upwelling, with subsequent deposition of basinal euxinic facies and diatomites lateral to the reefs, during tropical times.

The evaporites found now at the very margin of the Alboran Basin formed during the reflooding stage of the Mediterranean in small, adjacent basins that were silled and perched. Marine re-inundation took place in the late Messinian, making the Salinity Crisis therefore fully Messinian. Recolonization of a barren sea offered more chances for opportunistic organisms such as cyanobacteria, which for a time coexisted with normal marine biota, but then outcompeted it. This resulted in the widespread development of giant microbial carbonates (stromatolites and thrombolites) in the upper Messinian.

Messinian coral reefs survived the Salinity Crisis. They appear in the uppermost Messinian unit together with the giant microbial domes.

\section{ACKNOWLEDGMENTS}

This work was supported by DGICYT (Spain) Project PB93-1113 and by "Fundación Ramón Areces" Project: "Cambios climáticos en el sur de España durante el Neógeno.” We thank Christine Laurin for correcting the English text. 


\section{REFERENCES}

Baksi, A.K., 1993. A geomagnetic polarity time scale for the period 0-17 $\mathrm{Ma}$, based on ${ }^{40} \mathrm{Ar} /{ }^{39} \mathrm{Ar}$ plateau ages for selected field reversals. Geophys. Res. Lett., 20:1607-1610.

Benson, R.H., and Rakic-El Bied, K., 1991. The Messinian parastratotype at Cuevas de Almanzora, Vera Basin, SE Spain: refutation of the deep-basin shallow water hypothesis? Micropaleontology, 37:289-302.

Benson, R.H., Rakic-El Bied, K., and Bonaduce, G., 1991. An important current reversal (influx) in the Rifian Corridor (Morocco) at the TortonianMessinian boundary: the end of Tethys Ocean. Paleoceanography, 6:164-192.

Berggren, W.A., Kent, D.V., Swisher, C.C., III, and Aubry, M.-P., 1995. A revised Cenozoic geochronology and chronostratigraphy. In Berggren, W.A., Kent, D.V., Aubry, M.-P., and Hardenbol, J. (Eds.), Geochronology, Time Scales and Global Stratigraphic Correlation. Spec. Publ.Soc. Econ. Paleontol. Mineral. (Soc. Sediment. Geol.), 54:129-212.

Brachert, T.C., Betzler, C., Braga, J.C., and Martín, J.M., 1996. Record of climatic change in neritic carbonates: turnover in biogenic associations and depositional modes (Upper Miocene, Southern Spain). Geol. Rundsch., 85:327-337.

Braga, J.C., and Martín, J.M., 1992. Messinian carbonates of the Sorbas basin: sequence stratigraphy, cyclicity and facies. In Franseen, E.K., Goldstein, R.H., Braga, J.C., and Martín, J.M. (Eds.), Late Miocene Carbonate Sequences of Southern Spain: a Guidebook for the Las Negras and Sorbas Areas. In conjunction with the SEPM/IAS Research Conference on Carbonate Stratigraphic Sequences, Sequence Boundaries and Associated Facies, La Seu, Spain, 78-108.

__ 1996. Geometries of reef advance in response to relative sea-level changes in a Messinian (uppermost Miocene) fringing reef (Cariatiz reef, Sorbas Basin, SE Spain). Sediment. Geol., 107:61-81.

___ 1997. Evolución paleogeográfica de la cuenca de Sorbas y relieves adyacentes (Almería, SE España) en el Mioceno superior. In Calvo, J.P., and Morales, J. (Eds.), Avances en el conocimiento del Terciario Ibérico. Univ. Complutense de Madrid-Museo Nacional Ciencias Naturales, 61-64.

Braga, J.C., Martín, J.M., and Alcalá, B., 1990. Coral reefs in coarse terrigenous sedimentary environments (upper Tortonian, Granada basin, S. Spain). Sediment. Geol., 66:135-150.

Braga, J.C., Martín, J.M., Betzler, C., and Brachert, T.C., 1996b. Miocene temperate carbonates in the Agua Amarga Basin (Almería, SE Spain). Rev. Soc. Geol. Esp., 9:285-296.

Braga, J.C., Martín, J.M., and Riding, R., 1995. Controls on microbial dome fabric development along a carbonate-siliciclastic shelf-basin transect, Miocene, SE Spain. Palaios, 10:347-361.

__, $1996 \mathrm{a}$. Internal structure of segment reefs: Halimeda algal mounds in the Mediterranean Miocene. Geology, 24:35-38.

Carannante, G., Esteban, M., Milliman, J.D., and Simone, L., 1988. Carbonate lithofacies as paleolatitude indicators: problems and limitations. Sediment. Geol., 60:333-346.

Chevalier, J.P., 1961. Recherches sur les Madréporaires et les Formations Récifales Miocènes de la Méditerranée Occidental. Mem. Soc. Geol. Fr., 40:1-562.

Cita, M.B., 1991. Development of a scientific controversy. In Müller, D.W., McKenzie, J.A., and Weissert, H. (Eds.), Controversies in Modern Geology: Evolution of Geological Theories in Sedimentology, Earth History and Tectonics: London (Academic Press), 13-23.

Cita, M.B., Vismara-Schilling, A., and Bossio, A., 1980. Stratigraphy and paleoenvironment of the Cuevas del Almazora Section (Vera Basin): a reinterpretation. Riv. Ital. Paleontol. Stratigr., 86:215-240.

Cita, M.B., Wright, R.C., Ryan, W.B.F., and Longinelli, A., 1978. Messinian paleoenvironments. In Hsü K.J., Montadert, L., et al., Init. Repts. DSDP, 42 (Pt. 1): Washington (U.S. Govt. Printing Office), 1003-1035.

Claypool, G.E., Holser, W.T., Kaplan, I.R., Sakai, H., and Zak, I., 1980. The age curves of sulfur and oxygen isotopes in marine sulfate and their mutual interpretation. Chem. Geol., 28:199-260.

Comas, M.C., García-Dueñas, V., and Jurado, M.J., 1992. Neogene tectonic evolution of the Alboran Basin from MCS data. Geo-Mar. Lett., 12:157164.

Comas, M.C., Zahn, R., Klaus, A., et al., 1996. Proc. ODP, Init. Repts., 161: College Station, TX (Ocean Drilling Program).

Cunningham, K.J., Benson, R.H., Rakic-El Bied, K., and McKenna, L.W., 1997. Eustatic implications of late Miocene depositional sequences in the Melilla Basin, northeastern Morocco. Sediment. Geol., 107:147-165.
Cunningham, K.J., Farr, M.R., and Rakic-El Bied, K., 1994. Magnetostratigraphic dating of an upper Miocene shallow-marine and continental sedimentary succession in northeastern Morocco. Earth Planet. Sci. Lett., 127:77-93.

Dabrio, C.J., Esteban, M., and Martín, J.M., 1981. The coral reef of Níjar, Messinian (uppermost Miocene), Almería province, S.E. Spain. J. Sediment. Petrol., 51:521-539.

Dabrio, C.J., Martín, J.M., and Megías, A.G., 1982. Signification sédimentaire des évaporites de la depression de Grenade (Espagne). Bull. Soc. Geol. Fr., 24:705-710.

Dronkert, H., 1977. The evaporites of the Sorbas basin. Rev. Inst. Inv. Geol. Dip. Prov. Barcelona-Univ. Barcelona, 32:55-76.

Esteban, M., 1980. Significance of upper Miocene coral reefs of the Western Mediterranean. Palaeogeogr., Palaeoclimatol., Palaeoecol., 29:169-188.

Esteban, M., Braga, J.C., Martín, J.M., and Santisteban, C., 1996. Western Mediterranean reef complexes. In Franseen, E.K., Esteban, M., Ward, W.C., and Rouchy, J.M. (Eds.), Models for Carbonate Stratigraphy from Miocene Reef Complexes of Mediterranean Regions. Soc. Econ. Paleontol. Mineral., Concepts in Sedimentol. Paleontol. Ser., 5:55-72.

Esteban, M., Calvet, F., Dabrio, F., Baron, C., Giner, J., Pomar, L., Salas, R., and Permanyer, A., 1978. Aberrant features of the Messinian coral reefs. Acta Geol. Hisp., 13:20-22.

Fernández, J., Soria, J., and Viseras, C., 1996. Stratigraphic architecture of the Neogene basins in the central sector of the Betic Cordillera (Spain): tectonic control and base-level changes. In Friend, P.F., and Dabrio, C.J. (Eds.), Tertiary Basins of Spain: the Stratigraphic Record of Crustal Kinematics: Cambridge (Cambridge Univ. Press), World and Regional Geol. Ser., 6:353-365.

Fortuin, A.R., Kelling, J.M.D., and Roep, T.B., 1995. The enigmatic Messinian-Pliocene section of Cuevas del Almanzora (Vera basin, SE Spain) revisited: erosional features and strontium isotope age. Sediment. Geol., 97:177-201.

Garrett, P., 1970. Phanerozoic stromatolites: noncompetitive ecologic restriction by grazing and burrowing animals. Science, 169:171-173.

Gautier, F., Clauzon, G., Suc, J.-P., Cravatte, J., and Violanti, D., 1994. Age et durée de la crise de salinité messinienne. C. R. Acad. Sci. Paris, 318:1103-1109.

Geerlings, L.P.A., Dronkert, H., Van der Poel, H.M., and Van Hinte, J.E., 1980. Chara sp. in Mio-Pliocene marls at Cuevas del Almanzora, Vera Basin, Spain. Proc. Koning Nederl. Akad. Ser. B, 83:29-37.

Haq, B.U., Hardenbol, J., and Vail, P.R., 1987. Chronology of fluctuating sea levels since the Triassic. Science, 235:1156-1167.

Haughton, P.D.W., 1994. Deposits of deflected and ponded turbidity currents, Sorbas Basin, southeast Spain. J. Sediment. Res., 64:233-246.

Hodell, D.A., Mueller, P.A., McKenzie, J.A., and Mead, G.A., 1989. Strontium isotope stratigraphy and geochemistry of the late Neogene ocean. Earth Planet. Sci. Lett., 92:165-178.

Hsü, K., Montadert, L., Bernoulli, D., Cita, M.B., Erickson, A., Garrison, R.E., Kidd, R.B., Melieres, F., Müller, C., Wright, R.C., 1977. History of the Mediterranean salinity crisis. Nature, 267:399-403.

Hsü, K.J., Montadert, L., et al., 1978. Init. Repts. DSDP, 42 (Pt. 1): Washington (U.S. Govt. Printing Office).

Hsü, K.J., Ryan, W.B.F., and Cita, M.B., 1973. Late Miocene desiccation of the Mediterranean Sea. Nature, 242:240-244.

Iaccarino, S., Morlotti, E., Papani, G., Pelosio, G., and Raffi, S., 1975. Litostratigrafia e biostratigrafia di alcune serie neogeniche della provincia di Almería (Andalusia orientale-Spagna). Ateneo Parmense, Acta Nat., 11:237-313.

Jimenez, A.P., and Braga, J.C., 1993. Occurrence and taphonomy of bivalves from the Níjar reef (Messinian, Late Miocene, SE Spain). Palaeogeogr. Palaeoclimatol., Palaeoecol., 102:239-251.

Kendall, C.G.St.C., and Lerche, I., 1988. The rise and fall of eustacy. In Wilgus, C.K., Hastings, B.S., Kendall, C.G.St.C., Posamentier, H.W., Ross, C.A., and Van Wagoner, J.C. (Eds.), Sea-Level Changes: An Integrated Approach. Spec. Publ.-Soc. Econ. Paleontol. Mineral., 42:3-18.

Kleverlaan, K., 1989. Three distinctive feeder-lobe systems within one time slice of the Tortonian Tabernas fan, SE Spain. Sedimentology, 36:25-45.

Lees, A., and Buller, A.T., 1972. Modern temperate-water and warm-water shelf carbonate sediments contrasted. Mar. Geol., 13:1767-1773.

Martín, J.M., and Braga, J.C., 1991. Lower Messinian patch reefs and associated sediments, southeastern Spain. In Bosellini, A., Brandner, R., Flügel, E., Purser, B., Schlager, W., Tucker, M., and Zenger, D. (Eds.), Dolomieu Conference on Carbonate Platforms and Dolomitization, Val Gardena, The Dolomites (Italy): Innsbruck (KaroDruck), 161. (Abstract) 
, 1994. Messinian events in the Sorbas Basin in southeastern Spain and their implications in the recent history of the Mediterranean. Sediment. Geol., 90:257-268.

1996. Tectonic signals in the Messinian stratigraphy of the Sorbas Basin (Almería, SE Spain). In Friend, P.F., and Dabrio, C.J. (Eds.), Tertiary Basins of Spain: the Stratigraphic Record of Crustal Kinematics: Cambridge (Cambridge Univ. Press), World and Regional Geol. Ser., 6:387-391.

Martín, J.M., Braga, J.C., Betzler, C., and Brachert, T., 1996. Sedimentary model and high-frequency cyclicity in a Mediterranean, shallow shelf, temperate-carbonate environment (uppermost Miocene, Agua Amarga Basin, Southern Spain). Sedimentology, 43:263-277.

Martín, J.M., Braga, J.C., and Riding, R., 1993. Siliciclastic stromatolites and thrombolites, late Miocene, S.E. Spain. J. Sediment. Petrol., 63:131139

, 1997. Late Miocene Halimeda alga-microbial segment reefs in the marginal Mediterranean Sorbas Basin, Spain. Sedimentology, 44:441-456.

Martín, J.M., Ortega Huertas, M., and Torres Ruiz, J., 1984. Genesis and evolution of strontium deposits of the Granada Basin (southeastern Spain): evidence of diagenetic replacement of a stromatolite belt. Sediment. Geol., 39:281-298.

Martín-Pérez, J.A., 1989. Nannoplancton calcáreo del Mioceno superior en el S.E. de España: bioestratigrafía [Tesis de Licenciatura]. Univ. Granada.

Mather, A.E., 1993. Basin inversion: some consequences for drainage evolution and alluvial architecture. Sedimentology, 40:1069-1089.

Michalzik, D., Elbracht, J., Mauthe, F., Reinhold, C., and Schneider, B., 1993. Messinian facies relations in the San Miguel de Salinas basin, SESpain. Z. Dtsch. Geol. Ges., 144:352-369.

Montenat, C., 1990. Les bassins Néogènes du domaine bétique oriental (Espagne). Doc. Trav. IGAL, Paris, 12-13.

Müller, D.W., Hodell, D.A., and Ciesielski, P.F., 1991. Late Miocene to earliest Pliocene (9.8-4.5 Ma) Paleoceanography of the subantarctic Southeast Atlantic: stable isotopic, sedimentologic, and microfossil evidence. In Ciesielski, P.F., Kristoffersen, Y., et al., Proc. ODP, Sci. Results, 114: College Station, TX (Ocean Drilling Program), 459-474.

Müller, D.W., and Hsü, K.J., 1987. Event stratigraphy and paleoceanography in the Fortuna Basin (Southeast Spain): a scenario for the Messinian salinity crisis. Paleoceanography, 2:679-696.

Müller, D.W., and Mueller, P.A., 1991. Origin and age of the Messinian evaporites: implications from Sr isotopes. Earth Planet. Sci. Lett., 107:112.

Murray, J.W., 1991. Ecology and Palaeoecology of Benthic Foraminifera: London (Longman).

Nachite, D., 1993. Los ostrácodos y la evolución paleoambiental del Neógeno reciente del NO de Marruecos y del SE de España [Ph.D. dissert.]. Univ. de Granada, Spain.

Nelson, C.S., Head, P.S., and Keane, S.L., 1988. Non-tropical carbonate deposits on the Modern New-Zealand shelf. Sediment. Geol., 60:71-94.

Ott d'Estevou, P., 1980. Evolution dynamique du Bassin Neogène de Sorbas (Cordillères Bètiques Orientales, Espagne) [Thèse].

Paul, J., 1980. Upper Permian algal stromatolite reefs, Harz Mountains (F. R. Germany). Contrib. Sedimentol., 9:253-268.

Playà, E., Rosell, L., and Ortí, F., 1997. Geoquímica isotópica $\left(\delta^{34} \mathrm{~S},{ }^{87} \mathrm{Sr} /\right.$ ${ }^{86} \mathrm{Sr}$ ) y contenidos en estroncio de las evaporitas messinienses de la cuenca de Sorbas (Almería). In Calvo, J.P., and Morales, J. (Eds.), Avances en el Conocimiento del Terciario Ibérico. Univ. Complutense de Madrid-Museo Nacional Ciencias Naturales, 161-164.

Riding, R., Braga, J.C., and Martín, J.M., 1991a. Oolite stromatolites and thrombolites, Miocene, Spain: analogues of Recent giant Bahamian examples. Sediment. Geol., 71:121-127.

Riding, R., Braga, J.C., Martín, J.M., and Sánchez-Almazo, I.M., 1998. Mediterranean Messinian Salinity Crisis: constraints from a coeval marginal basin, Sorbas, SE Spain. Mar. Geol.,146:1-20.

Riding, R., Martín, J.M., and Braga, J.C., 1991b. Coral-stromatolite reef framework, upper Miocene, Almería, Spain. Sedimentology, 38:799-818.
Roep, T.B., Beets, D.J., Dronkert, H., and Pagnier, H., 1979. A prograding coastal sequence of wave-built structures of Messinian age, Sorbas, Almería, Spain. Sediment. Geol., 22:135-163.

Rouchy, J.M., 1980. La genèse des évaporites messiniennes de Méditerranée: un bilan. Bull. Cent. Rech. Explor-Prod. Elf-Aquitaine, 4:511-545.

1982. La genèse des évaporites messiniennes de Méditerranée. Mem. Mus. Nat. Hist. Nat., 50:1-267.

, 1986. Les évaporites miocènes de la Méditerranée et de la mer Rouge et leurs enseinements pour l'interprétation des grandes accumulations évaporitiques d'origine marine. Bull. Soc. Geol. Fr., 8:511-520.

Rouchy, J.-M., and Saint Martin, J.-P., 1992. Late Miocene events in the Mediterranean as recorded by carbonate-evaporite relations. Geology, 20:629-632.

Ruggieri, G., 1967. Miocene and later evolution of the Mediterranean Sea. In Adams, C.G., and Ager, A.V. (Eds.), Aspects of Tethyan Biogeography. Syst. Assoc. London Publ., 7:283-290.

Saint-Martin, J.P., and Rouchy, J.M., 1986. Intérêt du complexe récifal du Cap des Trois Fourches (Bassin de Nador, Maroc septentrional) pour l'interprétation paléogéographique des événements messiniens en Méditerranée occidentale. C. R. Acad. Sci. Paris, 302:957-962.

Sánchez-Almazo, I., Braga, J.C., and Martín, J.M., 1997. Palaeotemperature and sea-level control on carbonate deposition (Late Miocene, Sorbas Basin, SE Spain). Erice Conf. on Neogene Mediterranean Paleoceanography, Erice, Sicily. (Abstract)

Schubert, J.K., and Bottjer, D.J., 1992. Early Triassic stromatolites as postmass extinction disaster forms. Geology, 20:883-886.

Sears, S.O., and Lucia, F.J., 1979. Reef-growth model for Silurian pinnacle reefs, northern Michigan reef trend. Geology, 3:299-302.

Serrano, F., 1979. Los foraminíferos planctónicos del Mioceno superior de la cuenca de Ronda y su comparación con los de otras áreas de las Cordilleras Béticas [Ph.D. dissert.]. Univ. de Málaga, Spain.

Shackleton, N.J., 1984. Oxygen isotope evidence for Cenozoic climatic cooling. In Brenchley, P.J. (Ed.), Fossils and Climate: Chichester (Wiley), 27-34.

Sierro, F.J., Flores, J.A., Civis, J., González-Delgado, J.A., and Frances, G., 1993. Late Miocene globorotaliid event-stratigraphy and biogeography in the NE-Atlantic and Mediterranean. Mar. Micropaleontol., 21:143-168.

Sonnenfeld, P., 1985. Models of late Miocene evaporite genesis in the Mediterranean region. In Stanley, D.J., and Wezel, F.-C. (Eds.), Geological Evolution of the Mediterranean Basin: New York (Springer-Verlag), 347-353.

Troelstra, S.R., Van de Poel, H.M., Huisman, C.H.A., Geerlings, L.P.A., and Dronkert, H., 1980. Paleoecological changes in the latest Miocene of the Sorbas Basin, SE Spain. Geol. Mediterr., 7:115-126.

Van de Poel, H.M., 1991. Messinian stratigraphy of the Níjar basin (S.E. Spain) and the origin of its gypsum-ghost limestones. Geol. Mijnbouw., 70:215-234

_ 1994. Messinian marginal-marine and continental facies and their stratigraphy in the eastern Almería province (S.E. Spain). Strata, 23:1202.

Weijermars, R., 1988. Neogene tectonics in the Western Mediterranean may have caused the Messinian salinity crisis and an associated glacial event. Tectonophysics, 148:211-219

Williams, D.F., 1988. Evidence for and against sea-level changes from the stable isotopic record of the Cenozoic. In Wilgus, C.K., Hasting, B.S., Kendall, C.G.St.C., Posamentier, H.W., Ross, C.A., and Van Wagoner, J.C. (Eds.), Sea-Level Changes: an Integrated Approach. Spec. Publ.Soc. Econ. Paleontol. Mineral., 42:31-36.

Date of initial receipt: 23 May 1997 Date of acceptance: 1 December 1997 Ms 161SR-248 